\title{
The Attitude of the Community in the Preservation of the Samarinda City Forest
}

\author{
Fajar Apriani ${ }^{1, *}$ Santi Rande ${ }^{1}$

\begin{abstract}
${ }^{1}$ Public Administration Department of Social and Political Sciences Faculty,Mulawarman University, Samarinda, 75119, Indonesia
\end{abstract} \\ *Corresponding author. Email: yaniefajar@yahoo.com
}

\begin{abstract}
The rapid development of the city has made the green open space more limited, including for urban forest development in Samarinda. This study aims to analyze the attitudes of the community towards the preservation of the city forest of Samarinda. This research is a quantitative descriptive research using descriptive statistical data analysis from the survey method. The result showed that most people of the city of Samarinda did not know the entire green area of the city represented by the availability of urban forests and city parks, due to the lack of green areas, whereas the existence of urban forests is believed to be very beneficial for the balance of urban life on environmental quality. Besides that, the people of the city of Samarinda think that the policy of preserving green areas including urban forests needs to be a priority for the City Government in development, considering the total area of urban forests in Samarinda is only $0,96 \%$ of the total area of the city which reaches $718 \mathrm{~km}^{2}$. The availability of green open space in the city of Samarinda is also increasingly limited to be developed as urban forests.
\end{abstract}

Keywords: Rapid Development, Preservation, City Forest, Urban Forest

\section{INTRODUCTION}

The existence of urban forests is a component of green open space. Urban forest according to the Republic of Indonesia Ministry of Forestry Regulation Number P.17/Menhut-II/2009 concerning Guidelines for Implementing Urban Forests is an expanse of land that grows compact and dense trees in urban areas, both on state land and land rights, which are designated as urban forests by officials authorized. The purpose of the urban forest is to preserve, harmonize and balance the urban ecosystem which includes environmental, social and cultural elements. The function of urban forests is to improve and maintain the micro-climate and aesthetic values, absorb water, create a balance and harmony in the physical environment of the city and support the preservation of Indonesia's biodiversity [1,2].

In the Republic of Indonesia Government Regulation Number 63 of 2002 concerning Urban Forests stated that the functions of urban forests include: 1) improving and maintaining the micro-climate and aesthetic values, 2) absorbing water, 3) creating a balance and harmony in the physical environment of the city, 4) supporting conservation Indonesian biodiversity [3]. Therefore, the existence of urban forests has great benefits for improving the quality of the environment and people's lives in the city environment.

Specifically, concerning handling air pollution in urban areas, the existence of urban forests holds a very important function. Urban forest development can increase oxygen levels in the air so that it can neutralize pollutants in the air. The rapid development of the city makes the green open space more limited, including the existence of urban forests in Samarinda. Fulfillment of the needs of the population such as roads, settlements, offices, shopping centers to increase the number of motorized vehicle use has displaced the green open space in urban areas. The increasingly limited green open space will also be accompanied by the loss of various habitats of flora and fauna diversity and the decreasing function of water absorption. The availability of green open space in the city of Samarinda is increasingly limited to be developed as an urban forest, even though Article 8 of the Republic of Indonesia Government Regulation Number 63 of 2002 concerning Urban Forests [3] states that the government has an obligation to develop urban forests by $10 \%$ of its area.

With regard to this, the government needs to manage green open space through the development and 
management of urban forests in order to improve the quality of the urban environment. For the writer, besides that it is also necessary to care about the environment to preserve the forest and city parks in Samarinda which are very limited, considering the functions and benefits of forests and city parks for the balance of living beings. With the existence of a concern for the environment, environmental sustainability will be maintained and free from damage. Care means heed, pay attention. While in relation to the environment, Narwati explained that caring for the environment is an attitude and action that seeks to prevent damage to the surrounding natural environment and develop efforts to repair the natural damage that has already occurred [4].

In other words, caring for the environment is shown by a positive attitude towards the environment, such as maintaining an environmental balance and understanding the importance of maintaining environmental cleanliness. Hence the concern for the preservation of urban forests can be interpreted as attitudes and actions in daily life to protect and conserve the environment (especially urban forests), preventing it from repairing its damage.

Caring for the environment character is not entirely an innate talent or instinct, but is the result of an educational process. Care for the environment must be formed in each individual so that individuals can protect and preserve the environment [5]. Suparno expressed the attitude of environmental concern shown by the appreciation of nature. The essence of appreciation for nature is the realization that humans are part of nature, so loving nature means loving human life. If everyone loves the environment and nature, then everyone will care to preserve environmental survival, not damage and exploit which can have an impact later on in the form of an unfavorable environment [6].

This study examines the attitudes of the community in the preservation of urban forests in Samarinda so that the values of love for nature and environmental care are the focus of research in addition to the formation of attitudes formed by it. The difference between this research and other research is that this research is in the realm of specific public policy formulation on public hearing facilitation related to the issue of limited green open spaces in the city of Samarinda which includes forests and city parks. While other studies generally examine the realm of regional development, focussing on the analysis of the arrangement of green open spaces in urban areas as stated in [7]; [8], so that the aspects examined in the study of the author.

As the author's research focuses only on forests and city parks, there are also studies that only limit one of the urban forest areas, namely slaughterhouses in Lempake Village, North Samarinda District [9] and in urban forest areas in other cities as stated in [2]. In addition, there are also studies that make urban forests as objects of research, but in a broader scope than the author's research, namely in the Province of East Kalimantan. Another difference, the study is research on the realm of implementing public forestry policies [10]. There are also other studies which examine more about the attitude of concern for the environment which is not only limited to green open spaces as stated in [5]. Thus, the scope of previous research studies and the research conducted by the author contains several differences.

\section{RESEARCH METHODS}

This type of research is quantitative, where this study identifies the attitudes of the city of Samarinda and classifies and measures their opinions about the preservation of urban forests. Thus, through this type of research it can be explained in detail about the most dominant opinion of the city community of Samarinda regarding the attitude of concern for the preservation of urban forests, so that the result of the research can finally provide recommendations to the city government about green open spaces for the sustainability of the community and the environment.

The research location is the city of Samarinda which consists of ten sub-districts. So that the study population is the entire community of the city of Samarinda which is spread across the ten sub-districts. The number of research samples was 100 people according to the sample calculation based on Yamane formula [11] with a precision of $10 \%$. The sample is then taken from each sub-district through proportional or comparable allocations. The source of evidence for data collection of this study was obtained from a survey method conducted by distributing questionnaires about indicators of caring for urban forest sustainability for two weeks, namely at the beginning of August to midSeptember 2018. The survey results of all respondents were processed and analyzed based on the frequency distribution table and classification table.

\section{RESULT AND DISCUSSION}

\subsection{Respondents Characteristics}

Based on age, research respondents aged between 16 and 45 years. However, the highest number of respondents came from the age group of 21-25 years (26\%) and 16-20 years (25\%). Regarding the marital status of research respondents, most of the respondents $(55 \%)$ were unmarried, while others were married $(45 \%)$. Most $(65 \%)$ of the respondents were highly educated, i.e. $50 \%$ graduated or did not graduate from high school, and $30 \%$ received tertiary education, which consisted of $8 \%$ graduated from diploma III, $17 \%$ graduated from the university up to $5 \%$ passed the master's degree. The rest are low-educated, i.e. $20 \%$ have junior high school education (graduated or not 
graduated), but no one has only elementary school education or never attended school.

\subsection{City Forests in Samarinda}

The need for urban forests is an effort to overcome the decline in the quality of the urban environment. Several government regulations governing urban forest management, namely the Republic of Indonesia Law Number 63 of 2002 concerning Urban Forests, and the Republic of Indonesia's Forestry Minister's Regulation Number P.71/Menhut-II/2009 concerning Guidelines for Implementing Urban Forests. For the Province of East Kalimantan, regulations regarding green open space (including urban forests) are contained in the Regional Regulation of East Kalimantan Province Number 1 of 2016 concerning the Spatial Plan for the East Kalimantan Province in 2016-2036.

Based on ownership, green open space consists of private green open spaces and public green open spaces. Private green open spaces is a green open space owned by a particular institution or an individual whose use for a limited circle includes among other things a garden or yard of a house/building owned by public / private planted with plants while the public green open spaces are that which is owned and managed by the municipal/district government that is used for the benefit of the general public. Based on their physical condition, natural green open spaces in the form of natural wild habitats, protected areas and national parks. While non-natural green or built open spaces are like parks, sports fields, cemeteries or green paths [12].

The city of Samarinda is the capital of the Province of East Kalimantan which is growing with increasing population growth. The city of Samarinda is located along the Mahakam River and has rapid economic growth. The most striking problem in the city of Samarinda is the intensity of floods that tends to increase every year due to overflowing rivers or floods in times of heavy rainfall, poor drainage systems and loss of water catchment areas. As for several green open spaces in the city of Samarinda which has the Tepian as the city slogan (Shady, Neat, Safe and Comfortable) is shown in Table 1.

Based on the statistics of East Kalimantan Province in 2010, it is known that the area of the city of Samarinda is 71.800 hectares, with an area of urban forest covering an area of 691.1 hectares which is spread in 26 locations in five sub-districts. So that the percentage of the urban forest in that year was $0,96 \%$. The area of the urban forest in Samarinda is better than the area of the urban forest in Balikpapan $(0,39 \%)$ and Bontang $(0,04 \%)$, but not better than the area of the urban forest in Tarakan $(2,17 \%)$ [5].
Then based on the research "Evaluation of the Extent and Distribution of the Urban Forest of Samarinda" it is known that based on the Decision of Samarinda Mayor Number 224 in 1992, the area of the urban forest of the city of Samarinda was 218.77 hectares with the determination of 12 urban forest locations. Whereas based on the Samarinda Mayor's Decision Number 178/HK-KS/2005 the area of the city of Samarinda forest is around 690.23 hectares with the determination of 25 urban forest locations. Subsequently, in 2013 the calculation of urban forest area using ArcGIS 10.1 software was based on the Quick Bird image, the result showed that the urban forest area in Samarinda was 586.43 hectares. Thus, there will be a reduction in the urban forest area of 103.8 hectares.

Deddy Hadriyanto, Chairman of the Center for Climate Change Studies at Mulawarman University, stated that the conversion of forest land into coal mining resulted in $0,9 \%$ of the remaining urban forest from the total city area of 71.800 hectares. But in April 2014, Nusyirwan Ismail, Deputy Mayor of Samarinda at the time, stated that this was due to a large number of urban forests being demolished into settlements [13]. Thus, despite an increase in the area and number of urban forest areas, fulfilling the percentage of $10 \%$ of the urban forest from the city area in accordance with the Government Regulation of the Republic of Indonesia Number 63 of 2002 has not been reached.

\subsection{The Attitude of the Community in the Preservation of the Samarinda City Forest}

Based on the results of questionnaires that have been collected, it is known that several respondent opinions regarding their attitudes in the preservation of forests and city parks in Samarinda are as follows:

1. Public knowledge about forests and city parks in Samarinda.

In the city of Samarinda, there are 25 forest locations and city parks. The community of the city of Samarinda in general $(64 \%)$ knows less than half of the total number of forests and urban parks in Samarinda. This shows that the socialization carried out by the government on the existence of green open spaces in the form of forests and city parks is still very lacking so that the community also has limited knowledge about forest areas and city parks in Samarinda. If community knowledge about forest areas and city parks are still limited, then community involvement in forest and city parks conservation will be limited. 
Table 1. Green Open Spaces in the City of Samarinda

\begin{tabular}{|c|c|c|c|c|}
\hline No. & Location & Kelurahan & Kecamatan & Area (ha) \\
\hline 1 & Mesra Hotel & Bugis & Samarinda Ulu & 2,300 \\
\hline 2 & Voorfo Developmet Road & Air hitam & Samarinda Ulu & 0,480 \\
\hline 3 & City Hall & Bugis & Samarinda Ulu & 7,640 \\
\hline 4 & Mahakam bridge & & & 1,500 \\
\hline 5 & Mulawarman University & Gunung Kelua & Samarinda Ulu & 49,000 \\
\hline 6 & PT Hartaty & Loa Buah & Sungai Kunjang & 60,000 \\
\hline 7 & PT Gani Mulya & Harapan baru & Samarinda Seberang & 0,970 \\
\hline 8 & PT Sumber Mas & & & 85,000 \\
\hline 9 & PT Sumalinda & Harapan Baru & Samarinda Seberang & 3,600 \\
\hline 10 & Garden tomb of heroes & Bugis & Samarinda Ulu & 0,520 \\
\hline 11 & The urban behind the mayor's & Gunung Kelua & Samarinda Utara & 1,750 \\
\hline 12 & PT. Kiani Teluk Cinta & Selili & Samarinda llir & 6,000 \\
\hline 13 & Public high school 10 & Harapan Baru & Samarinda Seberang & 5,000 \\
\hline 14 & $\begin{array}{l}\text { Mulawarman University } \\
\text { botanical garden }\end{array}$ & Lempake & Samarinda Utara & 300,000 \\
\hline 15 & City government land & Harapan Baru & Samarinda Seberang & 5,000 \\
\hline 16 & Asih Manuntung & Gunung Kelua & Samarinda Utara & 0,250 \\
\hline 17 & Pesantren Hidayatullah & Sempaja & Samarinda Utara & 1,000 \\
\hline 18 & $\begin{array}{l}\text { City govemment land at } \\
\text { Makroman }\end{array}$ & Makroman & Samarinda llir & 167,000 \\
\hline 19 & Integrated agricultural land & & & 20,000 \\
\hline 20 & The throw of lempake & Lempake & Samarinda Utara & 3,500 \\
\hline 21 & Pesantrem Nabil Husien & Loa Bakung & Sungai Kunjang & 9,750 \\
\hline 22 & Pesantren Syachona Cholil & Sempaja & Samarinda Utara & 0,250 \\
\hline 23 & Slaughterhouse & Lempake & Samarinda Utara & 2,000 \\
\hline 24 & $\begin{array}{l}\text { Softball field environment Segiri } \\
\text { sports building }\end{array}$ & Bugis & Samarinda Ulu & 0,500 \\
\hline 25 & Samarinda city library & Air Hitam & Samarinda Ulu & 0,600 \\
\hline 26 & $\begin{array}{l}\text { Faculty of Agriculture } \\
\text { Mulawarman University }\end{array}$ & Gunung Kelua & Samarinda Utara & 6,500 \\
\hline \multicolumn{4}{|c|}{ Total } & 691,110 \\
\hline
\end{tabular}

2. Public knowledge about the functions of forests and city parks.

The function of the urban forest to improve the quality of the environment and the life of the urban community includes aesthetic, ecological, climatological, hydrological, protective, hygienic and educative benefits. Based on the results of the study it is known that the people of the city of Samarinda in general $(60 \%)$ know more than half of the overall function of the forest and city parks. This shows that the knowledge of the city of
Samarinda regarding the function of forests and city parks is in a good category.

3. Public awareness of the values of love for nature.

The belief and appreciation of the values of love for nature will also underlie the emergence of caring behavior towards environmental sustainability, including the forests and city parks. Based on the results of research it is known that the people of the city of Samarinda in general $(50 \%)$ are quite concerned about the values of love for 
nature. This shows that in addition to having a good knowledge regarding the function of forests and city parks for the balance of life, the people of the city of Samarinda also have a fairly good appreciation of the values of love for nature. Thus, the community of the city of Samarinda has a sufficient basis to have a caring attitude towards the preservation of forests and city parks.

4. Public understanding of the importance of the balance of human life and nature.

Based on the results of the study it is known that the people of the city of Samarinda in general $(66 \%)$ understand that between human life and nature there is a need for balance. This shows that in addition to having a fairly good appreciation of the values of love for nature, the people of Samarinda also understand the importance of the balance of life between human life and nature.

5. Environmental care behavior that is owned by the community.

Based on the results of the study it is known that the people of the city of Samarinda in general $(60 \%)$ have a high level of environmental concern in conserving forests and city parks. This shows that the people of the city of Samarinda have a fairly good appreciation of the values of love for nature, also understand the importance of the balance of life between human life and nature, so that the level of concern for the environment contained in the awareness of preserving forests and city parks is also high.

\section{CONCLUSION}

The limited forest and city park in Samarinda as a green open space makes the City Government of Samarinda need to add and develop a wider green open space to balance the life of the people of Samarinda. Related to the attitudes of the city of Samarinda towards the preservation of urban forests, it is known that they have a fairly good appreciation of the values of love for nature, so that the level of concern for the environment contained in the awareness of preserving forests and city parks is also high. However, the lack of socialization regarding the existence of green open spaces in the form of forests and city parks along with their functions and benefits for the balance of human and natural life by the city government can limit the involvement of the community in forest conservation and parks in Samarinda. The potential of the community of the city of Samarinda which can maintain the behaviour of caring for the preservation of forests and city parks can be in vain when the City Government does not play an optimal role in involving the community for this matter.

\section{REFERENCES}

[1] The Republic of Indonesia Ministry of Forestry Regulation Number P.71/Menhut-II/2009 concerning Guideline for Implementing Urban Forests.

[2] J. Silalahi, R.O.P. Situmorang, Persepsi dan Peran Masyarakat dalam Pengembangan Hutan Kota di Kota Medan Sumatera Utara, Prosiding Ekspose Hasil Penelitian Tahun 2014 Balai Penelitian Kehutanan Aek Nauli https://www.researchgate.net/publication/2734512 24 accessed at July 23, 2018.

[3] The Republic of Indonesia Government Regulation Number 63 of 2002 concerning Urban Forests.

[4] S. Narwanti, Pendidikan Karakter Pengintegrasian 18 Nilai Pembentuk Karakter dalam MutuPelajaran Yogyakarta Familia, 2011

[5] A. Handayani, Peningkatan Sikap Peduli Lingkungan melalui Implementasi Pendekatan Sains Teknologi Masyarakat (STM) dalam Pembelajaran IPA Kelas IV.1 SDN Keputran "A" Fakultas Ilmu Pendidikan Universitas Negeri Yogyakarta, 2013

[6] S. Azwar, Sikap Manusia Teori dan Pengukurannya, Pustaka Pelajar Yogyakarta, 2002

[7] A. P. Ramdani, S. R. P. S. Sitorus, B. Sulistyantara AnalisisRuang Terbuka Hijau (RTH) dan Keterkaitannya dengan Kenyamanan Kota Bogor Institut Pertanian Bogor, 2015, https://repository.ipb.ac.id/handle/123456789/7893 $\underline{4}$ accessed at July 23, 2018

[8] M. H. Rahmadi, Survey Keamanan dan Kenyamanan Ruang Terbuka Hijau (RTH) Publik di Kota Samarinda Jurnal Ilmu Administrasi 141, 2017, http://dx.doi.org/10.31113/jia.v14i1.11 accessed at July 25, 2018

[9] I Sulistyanto, Penataan Ruang Terbuka Hijau (RTH) pada Kawasan Rumah Pemotongan Hewan (RPH) Samarinda sebagai Upaya Terciptanya Kawasan Hijau pada Koridor Bandara Sei Siring Samarinda, 2014, Jurnal Teknik Sipil dan Arsitektur

https://www.neliti.com/id/publications/142788/ accessed at July 23, 2018

[10] T. Wahyuni, I. Samsoedin, Kajian Aplikasi Kebijakan Hutan Kota di Kalimantan Timur, 2012, Jurnal Analisis Kebijakan Kehutanan 
https://www.researchgate.net/publication/3096547 90 accessed at July 25, 2018

[11] D. Rakhmat, Metode Penelitian Komunikasi, 1991, Bandung Remaja Rosdakarya.

[12] Indonesian Institute for Infrastructure Studies Ruang Terbuka Hijau Jakarta, 2016, https://www.penataanruang.com/ruang-terbukahijau-html accessed at July 30, 2018

[13] Y. S. Hardjanto, Sulitnya Mencari Hutan Kota di Samarinda, 2014, https://www/mongabay.co.id/2014/08/12 accessed at July 30, 2018 